Н. М. Малюга

канд. філол. наук, доцент

\title{
МОВОЗНАВСТВО В ПИТАННЯХ І ВІДПОВІДЯХ ДЛЯ ВЧИТЕЛЯ Й УЧНІВ 5 КЛАСУ
}

Статтю присвячено проблемі застосування результатів мовознавчих досліджень у практиці проведення вступних уроків з украӥнської мови.

До висвітлення важливих мовознавчих питань шкільного курсу української мови звертаємося не вперше. Свого часу ми обгрунтовували необхідність застосування результатів мовознавчих досліджень у курсі української мови в середній школі, окреслювали шляхи подолання хибної практики проведення вступних уроків загальнолінгвістичної тематики [2].

Чинними програмами передбачено, що курс української мови в будьякому класі середньої і старшої ланки розпочинається з висвітлення важливих для становлення цільної інтелектуальної особистості мовознавчих 
питань. Однак нерідко вчитель не усвідомлює значущості цих перших уроків, формально підходить до їх підготовки, з року в рік з пафосом виголошує завчені крилаті вислови про красу й багатство української мови, цитує одні й ті ж невмирущі слова класиків, карбує гасла, закликає плекати, оберігати, розвивати... Від такої промови, нехай і палкої, чути банальністю, нещирістю, що нівелює саму ідею прищеплення любові до рідної мови. Нова парадигма навчання вимагає відходу від трафарету, подолання застиглості багатьох сучасних уроків української мови.

Для досягнення освітньої мети вчителем особливо важливими є аргументовані відповіді на питання, чи є українська мова здатною повноцінно обслуговувати суспільство, чи мала вона в своїй історії й має для цього належні здобутки й ресурси, чому нині нагальною $є$ потреба через мову підвищувати інтелектуальний потенціал нації й усього народу України $[3,46]$.

Так, мовною змістовою лінією Програми для загальноосвітніх навчальних закладів з української мови 5-12 класи передбачено тему «Значення мови в житті суспільства. Українська мова - державна мова України». Згідно $з$ державними вимогами до рівня загальноосвітньої підготовки учень має розуміти значення мови в житті суспільства, роль української мови як державної в Україні $[6,21]$.

В аспекті реалізації соціокультурної змістової лінії з метою дослідження сфери відношень «Я і українська мова та література» рекомендовано для опрацювання тексти з теми «Українська мова - найбільша духовна цінність українського народу»; для побудови власних висловлювань учнів запропоновано тему «Мова - найцінніший скарб народу».

У рубриці «Нове в програмі і методиці» журналу «Урок української» за 2007 p. [5] уміщено розробку вступного уроку української мови в 5 класі, метою якого $є$ розширити відомості п'ятикласників про рідну мову, сформувати поняття «національна мова», «державна мова»; ознайомити учнів із статтею 10 Конституції України; формувати вміння аналізувати висловлювання, відтворювати деформований текст, складати невеликі тексти відповідно до комунікативного завдання; сприяти усвідомленню значення мови в житті суспільства й ролі української мови як державної в Україні $[5,46]$.

Навіть успішна реалізація цієї мети не може забезпечити всебічне розкриття теми «Значення мови в житті суспільства». Запропонованій методичній розробці, як і сучасним підручникам загалом, бракує інформації для допитливих, конкретних цифр.

У той же час хочемо відзначити, що для вчителя початкових класів на ринку друкованої навчальної продукції ще в 2006 р. 3'явився посібник «Цікаве мовознавство для молодших школярів»[4], який вирізняе високий рівень інформативності, глибина висвітлюваних питань, наукова достовірність поряд із доступністю викладу матеріалу. Автори новаторського посібника Г. С. Одинцова, Я. П. Кодлюк запорукою результативності навчання

$$
-143-
$$


визнають застосування на уроках рідної мови цікавинок різних видів: це насамперед цікава в пізнавальному плані інформація (розкриття історичних аспектів проблеми, етимології того чи іншого поняття тощо); це і «невідоме про відоме», тобто використання додаткових відомостей про те, що діти вже частково знають (такий підхід дає можливість по-іншому трактувати явища, які стали для учнів буденними); зведений цифровий матеріал, що $є$ базою для порівняння, узагальнення виучуваного, підкреслення його значущості $[4,3]$.

Отже, як свідчить позитивний досвід колег, нарешті необхідно відмовитися від тупцяння по колу «українська мова - мова калинова, мова калинова - українська мова». Щоб досягти усвідомлення п'ятикласниками значення мови в житті суспільства, пропонуємо виклад матеріалу в питаннях i відповідях.

\section{1. Скільки мов у світі? Які перспективи мовної динаміки?}

Учені називають різну кількість мов. За даними Академії наук Франції, населення земної кулі послуговується не менше як 2796 мовами. Німецькі вчені стверджують, що народи сучасного світу говорять на мовах, число яких перевищує 4000. За інформацією Інституту світового стеження у Вашингтоні, населення нашої планети розмовляє понад 6800 мовами. Як стверджують лінгвісти, 3 усіх мов добре вивчені лише 500; 1400 перебувають на межі вимирання (найбільша кількість їх в Австралії й США); дві третини мов не мають писемності.

У світі є близько 40 мовних сімей, кожна з яких включає від однієї до кількох сотень мов. Індоєвропейська сім'я (саме до неї належить більшість європейських мов, зокрема й українська) - найчисельніша, мовами цієї сім'ї говорить близько 45 \% усього населення земної кулі.

$€$ країни, які вирізняються серед інших тим, що їхнє населення послуговується великою кількістю мов. В Індії, наприклад, говорять 845 мовами і діалектами, а в Папуа-Новій Гвінеї - 869, тобто в середньому кожною 3 цих мов розмовляє біля 4 тисяч осіб.

Протягом останніх п'яти століть зникло від 4000 до 9000 мов. 3 урахуванням проблеми розмежування мов і діалектів, найбільша кількість мов, якими будь-коли говорили в світі, складає 10-15000. За теперішніх темпів зникнення в XXI ст. близько 90\% мов світу перетвориться в мертві або вимираючі; мають шанс вижити і повнокровно функціонувати лише 600 мов світу. Вимирання мов подібне до вимирання тварин і рослин, але для них цей показник сягає 50\%.

2. Чи рівноправні мови у своӥх шансах на виживання?

Десятьма мовами говорить половина землян, 250-ма - 96\%, а для решти 4\% людства рідні 90\% мов світу. Зрозуміло, що в такій пропорції знака рівності бути не може.

3. Чому зменшується кількість мов?

Основними причинами вимирання мов $€$ :

$$
-144-
$$


- зникнення традиційного способу життя, розпад або знищення племінних общин;

- переслідування, вигнання, вимирання носіїв етнічних мов;

- економічна вигода, яку надають престижні мови чи мови респектабельних прошарків суспільства.

4. Чи можна мову відродити?

Відродження мови - це процес повернення вимерлої мови до повсякденного вжитку. Цей процес $є$ зворотним до вимирання мови, коли іiї носії поступово переходять до використання іншої мови в більшості життєвих ситуацій і перестають навчати старій мові своїх дітей. Відродження ставить метою повернути вимерлу чи вимираючу мову до загального активного вжитку і створити умови ії подальшого самостійного функціонування. Цей процес може запроваджуватися державною владою, суспільними чи культурно-освітніми організаціями й ентузіастами.

Мабуть, найуспішнішим прикладом такої діяльності є іврит - відроджена давньоєврейська мова, яка була мертвою протягом двох тисячоліть й існувала лише як літургійна мова іудаїзму. Нині іврит є державною мовою Ізраїлю, він уживається в усіх галузях суспільного й приватного життя. Інші проекти «порятунку» мов, яким загрожує вимирання, наприклад, відродження ірландської мови в Ірландії, мали значно менший успіх.

За різних часів державними установами чи громадськими організаціями і спільнотами ентузіастів проводилися кампанії, спрямовані на відродження таких мов, як:

- білоруська;

- бретонська - кельтська мова північного заходу Франції;

- валійська - кельтська мова Уельсу;

- idиu - германська мова євреїв Східної Європи;

- грецька катаревуса - проект часткового відродження давньогрецької мови, доконечного успіху не мав, але здійснив значний вплив на розвиток народної новогрецької мови;

- мова індіанського народу команчів;

- коптська - літургійна мова єгипетських християн, яка $є$ пізньою формою давньоєгипетської мови перших сторіч н. е.;

- корнуольська - кельтська мова південного заходу Англії, вимерла 3 XVIII ст.;

- ладино - мова євреїв, вигнаних з Іспанії в XVI ст., є результатом незалежного розвитку середньовічної іспанської мови;

- латинська - вимерла з раннього середньовіччя, але до XIX ст. була лінгва-франка в Свропі;

- менська - кельтська мова корінного населення острова Мен в Ірландському морі, що належить Великобританії, вимерла в ХІХст.;

- нюношк - одна 3 двох офіційних форм норвезької мови;

- провансальська - романська мова південного сходу Франції;

$$
-145-
$$


- mлінгіт - мова одного з індіанських народів Аляски;

- фарерська - скандинавська мова мешканців Фарерських островів, які належать Данії, зараз є офіційною на островах;

- фризька - германська мова північного сходу Нідерландів і суміжних областей Німеччини;

- шотландська - місцева форма англійської мови, що розвивалася окремо 3 середньовічних часів;

- шотландська гельська - мова кельтського населення Шотландії.

В історії людських суспільств можна спостерігати прогрес і регрес. Проте ні перше, ні друге поняття не мають сенсу по відношенню до історії мов. У зв'язку із занепадом якогось суспільства скорочується число тих, хто розмовляє його мовою. Тут ідеться про регрес суспільства, а не про зміну якості його мови. Обмеження застосування якоїсь мови не $\epsilon$ ще зміною їі якості.

5. Які європейські мови потребують захисту?

Мови, якими послуговується незначна кількість носіїв і їх чисельність має динаміку до зменшення, потребують підтримки з боку держав, дієвих заходів щодо збереження. Малі мови Свропи, що знаходяться в «групі ризику»:

- гельська (88000 носіїв);

- менська (померла в 1974, відроджена в 1980);

- ірландська (700000 носіїв, регулярно послуговуються 120000 осіб);

- валлійська (575000 носіїв);

- корнська (померла в XIX ст., відроджена в XX ст.);

- окситанська (поширена в селах на півдні Франції);

- гасконська (25000 носіїв);

- каталонська (10000000 носіїв);

- ладинська (35000 носіїв);

- фріульська (6000 носіїв);

- бретонська (близько 1000000 носіїв, регулярно послуговуються 500000 осіб);

- істрорумунська (147000 носіїв);

- арумунська (5000 носіїв);

- верхньо- і нижньолужицька (67000 носіїв);

- фризька (720000 носіїв);

- фарерська (47000 носіїв);

- люксембурзька (335000 носіїв);

- галісійська;

- баскська;

- романська;

- македонська $[1,213]$. Інформація щодо кількості носіїв останніх у переліку мов нам не відома.

6. Як сучасні засоби масової інформації можуть виконувати функиію «Червоної книги» для мов? 
Можливості засобів масової інформації для збереження етнічних мов:

- забезпечувати радіоефір усіма малими мовами, як це зараз здійснюється, наприклад, ладинською, романшською;

- підтримувати і розширювати спілкування в Інтернеті (нині використовуються галісійська, окситанська, гасконська мови, мови австралійських аборигенів);

- застовувати сучасні мультимедійні технології для запису мовлення етнічних носіїв.

7. Скільки штучних мов існує в світі і навіщзо їх створюють?

Ідея спільної для всіх людей мови давно привертала увагу вчених. Над цією проблемою працювали Ян Амос Коменський, Френсіс Бекон, Готфрід Вільгельм Лейбніц, Ісаак Ньютон та ін. Але нікому не спадало на думку замінити всі існуючі мови якоюсь однією, навіть найбільш поширеною. Відомо понад 900 проектів штучних мов (за даними 1991 року - 912), із них лише 6 використовуються як справжні мови (це волапюк, есперанто, ідо, латіна сіне флексіоне, окціденталь, інтерлінгва).

Долі в штучних мов, як і природних, різні. Есперанто, наприклад, звучить на всесвітніх конгресах, у клубах есперантистів, понад тридцять радіостанцій світу здійснюють трансляцію цією мовою. Інші ж мови (a їх домінуюча більшість) відомі лише вузькому колу спеціалістів, наприклад слов'янське есперанто. Так, зовсім нещодавно в Інтернеті запрацював блог під назвою «Slovianska gazeta / Словианска газета»[7]. Що ж це за проект?

Словианска газета јесть вебсајт писани посредствем јазик Словиански-П. Много сто милиони словјани розумејут јего непосредно и безусилијно. Словиански-П употребја слова взјата из руски, польски и ине словјанске јјазики. Идеально для путованије!

Таке пояснення міститься на першій сторінці самого он-лайнвидавництва. I, якщо хто не зрозумів, газета виходить новою штучною мовою Slovianski-P, вибудованою на основі сучасних слов'янських мов. Між іншим, путованије по-словіанському означає «мандрівка». Але наводить на думку про плутанину.

Найбільш активним автором проекту є чех Габрієль Свобода. Робота над створенням нової мови розпочалася в березні 2006 року, і ось уже з'явився більш-менш живий продукт на Slovianski-P - «Словианска газета».

Лінгвістичний експеримент, поставлений Габрієлем Свободою, цікавий з дослідницької точки зору, як і будь-яка інша штучна мова. Викликає повагу кропітка праця 3 добору загальнослов'янських слів та побудови граматичних правил. Можливо, слов'янське есперанто навіть має певне майбутнє і в практичному плані: наприклад, його можна використовувати для спілкування в Інтернеті, тоді не доведеться ламати голову над вимовою. Ця мова була б зручною для різноманітних видів Інтернет-розсилок, розрахованих на декілька слов'янських країн одночасно: замість перекладу польською, сербською, російською тощо можна забезпечити переклад 
Словиански-П - оперативно і нікому не образливо. Адже і скандинави схильні змішувати свої мови, спілкуючись між собою.

8. Який обсяг словникового запасу людини достатній для забезпечення комунікативної функиії мови?

У середньому ми говоримо годину на день, за все життя - два 3 половиною роки. А якщо записати все, сказане нами, то вийде тисяча томів по 400 сторінок у кожному.

Кажуть, що двох-трьох тисяч слів цілком достатньо для розмови, якщо тільки вона не стосується наукових проблем, а ведеться на побутовому рівні (хоча переважна більшість людей із середньою освітою розуміє значення близько 35 тисяч слів). Словник мови прозових творів Тараса Шевченка охоплює понад 20 тисяч слів, а поетичних - понад 10 тисяч. Проте мови первісних племен налічують не більше 200 слів, а Елочка Щукіна 3 роману Іллі Ільфа і Євгена Петрова «Дванадцять стільців» знала лише 30 слів, яких їй було цілком достатньо, щоб спілкуватися з іншими.

До речі, до слова «говорити» словник української мови подає понад 50 синонімів з усіма емоційними відтінками.

9. Чи можна розробити універсальний алфавіт для всіх мов світу?

Учені вже не перший рік думають над тим, як створити алфавіт, єдиний для всієї планети. Щось подібне вдалося винайти азербайджанському лінгвісту Алімамеду Набібейлі, який витратив на це майже півстоліття. Універсальний «алфавіт дружби», як назвав його автор, нараховує всього дев'ять букв - сім на позначення приголосних звуків і дві на позначення голосних. Учений переконаний, що цих букв достатньо, щоб передати на письмі будь-який звук кожної із тисяч мов планети $[4,30]$.

10. I нарешті останнє питання, порядковий номер якого символічно збігається з номером найважливішої в мовознавчому аспекті статті Конституції України, яка засвідчує державний статус української мови: Чи можуть місиеві органи самоврядування надавати певній мові статусу регіональної?

Для відповіді наведемо типовий факт спекулятивного прочитання чинних документів, що регламентують функціонування мов в Україні. Так, 10 жовтня 2006 року Дзержинський районний суд м. Кривого Рогу розглянув адміністративну справу за позовом прокурора в інтересах держави в особі Міністерства юстиції України, Кабінету Міністрів України до Криворізької міської Ради Дніпропетровської області про визнання протиправним та скасування iї ж рішення за №176 від 21 червня 2006 року «Про заходи щодо забезпечення положень Європейської хартії регіональних мов або мов меншин стосовно російської мови на території міста».

В обгрунтування своїх вимог прокурор послався на те, що зазначене рішення прийняте поза межами компетенції Криворізької міської Ради, оскільки відповідно до Конституції України, Закону Української РСР «Про мови в Українській РСР» питання про надання тій чи іншій мові статусу

$$
-148-
$$


регіональної вирішується шляхом прийняття відповідних законів, а не рішень місцевого самоврядування. 3 цих підстав прокурор просив позов задовольнити та визнати протиправним і скасувати оскаржуване рішення.

За даними Всеукраїнського перепису населення, проведеного у 2001 році, у м. Кривому Розі більшість населення української національності - 561 тис. громадян (або 79,9\%), тоді як громадян російської національності - 125 тис. (або 17,7\%), а тому використання терміна регіональна мова стосовно до російської мови не відповідає положенням ст.1 Європейської хартії регіональних мов або меншин.

Чинним законодавством та Законом України «Про ратифікацію Європейської хартії регіональних мов або меншин» не визначено порядок та процедури запровадження заходів на певній території регіональних мов та меншин, передбачених хартією, а також не встановлено межі їх застосування.

Відповідно до п.50 ст.26 Закону України «Про місцеве самоврядування» до виключної компетенції сільських, селищних та міських рад віднесено вирішення відповідно до закону (підкреслення наше - Н. М.) питання про мову (мови), якою послуговується в своїй роботі рада, ії виконавчий орган та яка використовується в офіційних оголошеннях.

Ані законом «Про місцеве самоврядування в Україні», яким визначено повноваження органів місцевого самоврядування, ані іншими законами нашої держави не надано право місцевим радам вирішувати питання щодо застосування як регіональних тих чи інших мов. Отже, компетенція визнавати ту чи іншу мову регіональною належить виключно державі.

Суд постановив позов прокурора м. Кривого Рогу задовольнити повністю, зокрема визнати протиправним та скасувати рішення Криворізької міської Ради за №176 від 21 червня 2006 року «Про заходи щодо забезпечення положень Європейської хартії регіональних мов або мов меншин стосовно російської мови на території міста».

Отже, нова інформаційна доба і нові вимоги до якості навчального процесу змушують учителя переорієнтувати викладання уроків загальнолінгвістичної тематики. Підгрунтям досягнення освітньої мети є використання в навчальному процесі інформаційно насичених матеріалів, зокрема 3 елементами порівняльного й історичного мовознавства. Грамотно дібраний і раціонально поданий пізнавальний лінгвістичний матеріал забезпечить стійкий інтерес учнів до мови не лише як навчальної дисципліни, а i як самобутнього явища.

\section{Список використаної літератури}

1. Атлас языков мира.-Словакия: Лик пресс, 1988.-224 с.

2. Малюга Н. М. Мовознавство: упровадження результатів пізнання в практику сучасної школи // Актуальні проблеми філології і методики викладання мов: Зб. наук. праць. - Кривий Ріг. Вид-во Криворізьк. пед. ун-ту, 2004. - С. 160164 // Вересень. - 2005. - №1-2. - С. 14-19. 
3. Муромцев I. В. Питання духовної культури в курсах історії української мови та історії українського мовознавства // Українська духовна культура в системі національної освіти: Тези доповідей та повідомлень наукової конференції 1819 квітня 1995 р. - Х.: Вид-во ХДУ, 1995. - С.45-47.

4. Одинцова Г. С., Кодлюк Я. П. Цікаве мовознавство для молодших школярів: Посібник для вчителя початкових класів. - К.: Наш час, 2006. -123 с.

5. Омельчук С. Вступні уроки української мови (5 клас) // Урок української. 2007. - №5. - C.46-49.

6. Українська мова 5-12 класи: Програма для загальноосвітніх навчальних закладів: Навчально-практичне видання. - К.: Вид-во ВТФ «Перун», 2005. - 176 с.

7. http:/eursa. org/node/1337/print.

\section{Summary}

The paper is devoted to the problem of applying the results of linguistic studies in the practice of giving introductory lessons of Ukrainian. 